\title{
СТРУКТУРА МЕХАНІЗМУ УХВАЛЕННЯ СУДОВИХ РІШЕНЬ У ЦИВІЛЬНОМУ СУДОЧИНСТВІ
}

Прохоров П. А.

\begin{abstract}
Метою статmі є системний аналіз різних умов, факторів, обставин, що визначають процес і результат прийняття судом рішення в цивільному судочинстві, й виявлення єдиного механізму прийняття судом рішення.
\end{abstract}

Досліджено структурні елементи механізму прийняття судового рішення, до яких може бути віднесено: суб'єкти діяльності з прийняття рішень, що володіють певним колом повноважень; об'єкт судового рішення; мета ухвалення судового рішення; підстави ухвалення судового рішення; етапи ухвалення судового рішення.

Стверджується, що єдиним суб'єктом ухвалення рішення є суд, тоді як додаткові суб'єкти, що впливають на прийняття рішень, - учасники справи, які мають зацікавленість у результатах розгляду справи, й вищий суд, - не можуть бути віднесені до суб'єктів ухвалення судових рішень.

Розглядається, що об'єкт судового рішення - це конкретне питання, яке має бути розв'язано судом, а метою ухвалення кожного судового рішення $\epsilon$ реалізація основного завдання цивільного судочинства - справедливого, неупередженого й своєчасного розгляду й розв'язання цивільних справ із метою ефективного захисту порушених, невизнаних або спростовуваних прав, свобод чи інтересів фізичних осіб, прав та інтересів юридичних осіб, інтересів держави.

Сукупність підстав прийняття судового рішення залежить від його характеру. В окремих випадках підстави прийняття рішення прямо встановлюються нормами закону, а в інших випадках - визначаються судом з урахуванням конкретної ситуації та впливу прийнятого судового рішення на виконання завдань цивільного судочинства.

Визначено такі етапи ухвалення судового рішення: 1) встановлення та дослідження фактичних обставин справи; 2) юридична кваліфікація справи; 3) винесення та оформлення рішення уповноваженим суб'єктом правозастосування.

Ключові слова: судове рішення, механізм ухвалення судового рішення, етапи ухвалення судового рішення, ухвала, цивільний процес.

Prokhorov P. A. Structure of judicial decision making mechanism in civil proceedings

Purpose of the article is a systemic analysis of various conditions, factors and circumstances determining the process and outcome of judicial decision making in civil court proceedings and identification of a single judicial decision making mechanism.

The paper contains study of structural elements of judicial decision making mechanism, which may include: decision makers with a certain scope of powers, subject of judicial decision, purpose of judicial decision making, grounds for judicial decision making, stages of judicial decision making.

The article states that court is the only decision maker, and additional parties affecting the process of decision making, such as parties to the case interested in outcome of case hearing and court of superior jurisdiction, cannot be viewed as judicial decision makers.

The paper further claims that subject of judicial decision is a specific matter to be decided by the court, and purpose of any judicial decision making is achievement of the main task of civil court proceedings, i.e. fair, unbiased and timely hearing and settlement of civil cases for the purpose of effective protection of infringed, nonrecognized or challenged rights, freedoms or interests of individuals, rights and interests of legal entities and interests of the state.

Totality of grounds for judicial decision making depends on nature thereof. In certain cases grounds for judicial decision making are expressly stipulated by statutory provisions, and in other cases they are established by the court in view of specific situation and impact of the judicial decision on achievement of the tasks of civil court proceedings.

The following stages of judicial decision making are identified: 1) establishment and study of facts of the case; 2) legal classification of the case; 3) decision making and execution by an entity authorized to administer the law.

Key words: judicial decision, judicial decision making mechanism, stages of judicial decision making, ruling, civil procedure.

Постановка проблеми та їі актуальність. Ухвалення судового рішення - складний процес, у ході якого між собою взаємодіють суб'єкти цивільно-процесуальних правовідносин; здійснюються різні види діяльності, найважливішими 
з яких $є$ пізнавальна й правозастосовна. Механізм прийняття судового рішення традиційно розглядається як складова частина механізму правозастосування. Як і будь-яка правозастосовна діяльність компетентного органу, ухвалення судового рішення становить певну систему дій, що сприяє досягненню завдань цивільного судочинства.

Аналіз останніх досліджень i публікацій. Комплексний аналіз судового рішення як акту правосуддя був проведений І.В. Андроновим у дисертаційному дослідженні «Судові рішення в цивільному процесі України», однак не розв'язаним питанням залишилося дослідження механізму ухвалення судових рішень у цивільному судочинстві та його структура. Зазвичай дослідженням сказаної проблематики приділяється увага в інших процесуальних галузях права (Х.Р. Тайлієва, М.І. Труш) або в загальнотеоретичних дослідженнях процедури правозастосування (К.В. Николина).

Метою статті $\epsilon$ системний аналіз різних умов, факторів, обставин, що визначають процес і результат прийняття судом рішення в цивільному судочинстві, й виявлення єдиного механізму прийняття судом рішення в цивільних справах.

Виклад основного матеріалу. Н.А. Чертова й І.С. Юрінська вказують як елементи структури механізму прийняття судового рішення: питання, що вимагає розв'язання; фактичні обставини; принципи й норми права; мету, методи, правову свідомість судді, можливі альтернативи й саме рішення як вибір альтернативи. Дискусійність такого структурування пов'язана з включенням до механізму ухвалення судового рішення такого елементу, як вибір альтернативи - в разі, якщо в судді $\epsilon$ альтернатива (дискреція), йдеться про вибір відповідної норми права, тобто знову ж таки про правозастосування, а в деяких випадках у суду взагалі відсутня альтернатива через імперативність процесуального законодавства (наприклад, завершення процедури врегулювання спору за участі судді на підставі спливу відведеного процесуальним законодавством для цього 30-денного строку, закриття провадження з причини смерті сторони, якщо правовідносини не допускають правонаступництва тощо). Правосвідомість так само не може бути самостійним структурним елементом механізму прийняття рішення, оскільки вона хоч і впливає на процес прийняття рішення, однак $\epsilon$ елементом саме обрання та застосування суддею норми права: суд, оцінюючи обставини справи, застосовуючи норму права, робить необхідні висновки, виходячи з власної правосвідомості й розуміння справедливості.
Вважаємо, що до числа структурних елементів механізму прийняття судового рішення можуть бути віднесені: суб'єкти діяльності з прийняття рішень, що володіють певним колом повноважень; об'єкт судового рішення; мета ухвалення судового рішення; підстави ухвалення судового рішення; етапи ухвалення судового рішення.

1. Суб'єкти ухвалення судових рішень та їх повноваження. Єдиним суб'єктом ухвалення рішення $\epsilon$ суд. Зазвичай, це суд, який розглядає справу, однак у випадку встановлення необгрунтованості заявленого відводу розв'язання питання про відвід здійснюється суддею, який не входить до складу суду, що розглядає справу.

Залежно від кількісного складу суд поділяється на одноособовий і колегіальний, а останній своєю чергою поділяється на суд у складі виключно професійних суддів і змішаний суд (у складі професійного судді й двох присяжних). Особливі зв'язки виникають під час ухвалення судового рішення всередині колегіального складу суду, який, з одного боку, виступає як єдиний суб'єкт правозастосування, а з іншого, - може мати внутрішньо неоднорідну структуру, пов'язану як з участю непрофесійних суддів (присяжних), так і з відносною самостійністю кожного із членів колегії.

Водночас неможливо погодитися з позицією деяких науковців про наявність додаткових суб' $є к-$ тів, що впливають на прийняття рішень, - учасників справи, які мають зацікавленість у результатах розгляду справи, - а також вищий суд - в разі скасування винесеного нижчим судом рішення та передачі справи (матеріалів справи) на новий розгляд [1, с. 120]. Дійсно, їхній вплив у процесуальний спосіб на суддю іноді має вирішальне значення для формування внутрішнього переконання останнього: процес реалізації учасниками справи своїх прав та обов'язків як елемент змагальності цивільного судочинства сприяє формуванню предмета доказування та доказуванню. Водночас не можна вважати їхні дії аналогічними ухваленню судового рішення. Зокрема, в певних випадках сторона по справі може займати пасивну позицію під час судового розгляду - не подавати заяв по суті справи, інших заяв і клопотань і навіть не з'являтися в судові засідання. У певних випадках цивільне процесуальне законодавство врегульовує процес ухвалення судового рішення таким чином, щоб взагалі виключити можливість впливу учасника справи на рішення, що виноситься. Наприклад, у наказному провадженні судовий 
наказ видається лише за письмовими доказами стягувача, а позиція боржника матиме значення на пізнішому етапі під час розгляду заяви про скасування судового наказу. Іншим прикладом $\epsilon$ розгляд заяви про забезпечення позову без повідомлення учасників справи: лише у виняткових випадках, коли наданих заявником пояснень і доказів не досить для розгляду заяви про забезпечення позову, суд може призначити їі розгляд у судовому засіданні з викликом сторін.

Аналогічним чином учасники справи не можуть впливати на судові рішення, що ухвалюються з власної ініціативи (наприклад, щодо самовідводу, вимоги оригіналу електронного доказу, виклику експерта для надання усних пояснень, продовження процесуальних строків, скасування заходів забезпечення позову тощо) чи які суд зобов' язаний прийняти (наприклад, про відкриття провадження у справі в разі відсутності підстав для відмови у відкритті провадження).

Також не можливо погодитися з віднесенням вищих судових інстанцій до суб'єктів ухвалення рішення. Насамперед суди вищих інстанцій виконують свою контрольну функцію виключно після ухвалення судового рішення. Навіть наявність законодавчого положення щодо обов'язковості для суду першої чи апеляційної інстанції під час нового розгляду справи висновків суду касаційної інстанції, у зв'язку з якими скасовано судові рішення та спрямовано справу на новий розгляд (ст. 411 Цивільноправового кодексу (далі - ЦПК) України), не перешкоджає вільній оцінці доказів судом першої чи апеляційної інстанції. Висновки касаційного суду мають стосуватися тих порушень процесуального права, які мають бути усунуті під час нового судового розгляду, однак жодним чином не можуть стосуватися питань «правильного» розв'язання процесуального питання чи справи по суті (ст. 417 ЦПК).

2. Об'єкт судового рішення - це конкретне питання, яке має бути розв'язане судом. У ряді випадків для розв'язання основного питання суд повинен розглянути цілий ряд питань проміжного характеру. Так, приймаючи рішення про відкриття провадження у справі, суд з'ясовує відсутність підстав для залишення позовної заяви без руху, повернення позовної заяви чи відмови у відкритті провадження; за якими правилами позовного провадження (загального чи спрощеного) буде розглядатися справа; дату, час і місце підготовчого засідання чи судового засідання для розгляду справи по суті; результат вирішення заяв і клопотань позивача, що надійшли разом із позовною заявою, якщо їх вирішення не потребує виклику сторін; строк для подання відповідачем відклику на позов; строки для подання відповіді на відклик i заперечень, якщо справа буде розглядатися за правилами спрощеного позовного провадження; строк надання пояснень третіми особами, яких було залучено під час відкриття провадження у справі тощо.

Як правильно зазначає І.В. Андронов, існування принципово різних питань, що змушений розв'язувати суд у процесі відправлення правосуддя, породжує необхідність у різних процесуальних формах їх розв'язання: вирішення по суті цивільної справи (розв'язання правового спору між сторонами, надання відповіді на позовну вимогу) й вирішення заяви про виклик свідка - це принципово різні за своєю складністю завдання, а тому вони вимагають від суду різного обсягу зусиль, різних підходів до їх розв'язання, кількості досліджених матеріалів, ретельності обґрунтування висновків, застосування різних техніко-юридичних прийомів тощо. Крім того, вони спричиняють різні юридичні наслідки. Саме тому дуже важливо, щоб обсяг питань, які розв'язуються ухваленням того чи іншого процесуального акта, відповідав сутності такого акта й навпаки, ухвалений судом процесуальний акт повинен за своєю суттю відповідати розв'язаному ним питанню, тобто процесуальна форма повинна чітко відповідати юридичному змісту [2, с. 71].

Е.М. Мурадьян за характером поділяє судові акти на такі види: а) розпорядчі (виражають керувальну й організаційну роль судді в процесі); б) забезпечувальні (дозволяють оформити забезпечення позову, доказів, рішення); в) посвідчувальні (ухвала про затвердження мирової угоди сторін і закриття провадження у справі); г) підсумкові (рішення суду, що мають завершальний характер, в яких сформульований припис суду по суті справи, відповідь на основне чи декілька питань, поставлених перед судом позивачем (заявником)) [3, с. 651-652].

Коло питань, що розв'язується судовим рішенням, впливає і на його форму: цивільним процесуальним законодавством встановлюється обов'язкова письмова форма для рішень і постанов суду, судових наказів, тоді як ухвали можуть бути викладені як у письмовій формі, так і в усній. Причому ухвали, для яких законом передбачено письмову форму, не можуть бути винесені усно, тоді як усні ухвали можуть бути викладені за ініціативою суду письмово з виходом до нарадчої кімнати. Отже, за формою судові рішення поділяються на усні 
(вербальні) й письмові. А тому неможливо погодитися з позицією І.В. Андронова, який зазначає, що навіть судові ухвали, які не оформлюються у вигляді окремого процесуального документа й постановляються судом на місці, заносяться до протоколу судового засідання, а отже також мають письмову форму [2, с. 70]. Адже через приписи ст. ст. 259, 268 ЦПК України в ухвалі, яку суд постановляє без виходу до нарадчої кімнати, оголошуються висновок суду й мотиви, з яких суд дійшов такого висновку, й така ухвала заноситься до протоколу судового засідання.

Очевидно, що секретарем судового засідання в протоколі судового засідання не можуть бути повно відбиті мотиви проголошеної усно ухвали, іноді не вбачається за можливе повно зафіксувати й висновок суду (якщо в ньому, наприклад, озвучуються номери банківських рахунків, дати чи інша інформація, яку складно сприйняти на слух та оперативно зафіксувати). Тому зазвичай протокол судового засідання містить лише коротку резолюцію - чи задоволено заяву (клопотання) повністю або частково, чи відмовлено в задоволенні, або ж стислі відомості про рішення суду (наприклад, про час оголошеної перерви в судовому засіданні). Протокол судового засідання - це документ технічного характеру, який не дає можливості скласти уявлення про те, як саме відбувалося судове засідання (оскільки із цією метою проводиться аудіозапис), і відбиває в хронологічному порядку процесуальні дії, які вчинялися в судовому засіданні, а технічний запис містить інформацію про їх зміст.

3. Мета ухвалення судового рішення. Метою ухвалення кожного судового рішення $\epsilon$ реалізація основного завдання цивільного судочинства - справедливого, неупередженого й своєчасного розгляду й розв'язання цивільних справ із метою ефективного захисту порушених, невизнаних або спростовуваних прав, свобод чи інтересів фізичних осіб, прав та інтересів юридичних осіб, інтересів держави. Однак така загальна мета опосередковується проміжними цілями, пов'язаними з розв'язанням конкретного процесуального питання, яке сприятиме досягненню загальної мети.

Залежно від реалізації кінцевої мети правосуддя С.К. Загайнова пропонує виділяти: 1) остаточні судові акти, що завершують розгляд цивільної справи в рамках окремого судового провадження чи в межах окремого правозастосовного циклу; 2) проміжні судові акти, які супроводжують усю діяльність щодо здійснення правосуддя, спрямовані на ухвалення остаточного судового акту [4, с. 8]. Не завжди мета ухвалення судового рішення досягається за результатами розгляду справи: слід не погодитись з І.В. Андроновим, який вказує, що ухвали не призначені для розв'язання основної мети цивільного судочинства й не втілюють результату розгляду й розв'язання цивільної справи, оскільки розв'язують поточні процесуальні питання, що лише супроводжують здійснення правосуддя в цивільній справі. Дійсно, кожна конкретна ухвала не розв'язує спірних матеріальних правовідносин між сторонами, однак вона $є$ складовою частиною багатоетапного механізму розгляду й розв'язання цивільної справи.

Однак у визначених цивільним процесуальним законодавством випадках ухвалою суду завершується розгляд справи без винесення рішення. Зокрема, в разі закриття провадження у справі повторне звернення до суду з приводу спору між тими самими сторонами, про той самий предмет і з тих самих підстав не допускається (крім випадку відмови позивача від позову, якщо відповідач забажає розв'язати спір у судовому порядку). Дійсно, хоча в такому випадку матеріально-правовий спір не розв'язувався по суті, ухвалою суду стверджується або неможливість розгляду такого спору в порядку цивільного чи будь-якого іншого виду судочинства, або відсутність чи припинення предмету спору, або неможливість розв'язання спору у зв'язку з укладенням третейської угоди, наявності рішення третейського суду чи суду іноземної держави.

4. Підстави ухвалення судового рішення. Сукупність підстав прийняття судового рішення залежить від його характеру. В окремих випадках підстави прийняття рішення прямо встановлюються нормами закону (наприклад, підстави для скасування судового рішення повністю або частково й ухвалення нового рішення у відповідній частині або зміни рішення, підстави забезпечення позову, закриття провадження у справі тощо). В інших випадках - визначаються судом з урахуванням конкретної ситуації та впливу прийнятого судового рішення на виконання завдань цивільного судочинства. Наприклад, прийняття рішення про оголошення перерви у справі та іiі тривалість визначається судом, виходячи $з$ конкретних обставин, які не завжди пов'язані з ходом розгляду цивільної справи, а можуть залежати й від сторонніх чинників (можливість сторони чи iї представника з'явитися для продовження розгляду у визначений час, можливість заміни відведеного експерта тощо). 
5. Emanu ухвалення судового рішення. Конкретний зміст діяльності щодо прийняття судового рішення та необхідні для цього кроки розрізняються залежно від виду судового рішення, від того, на якій стадії цивільного судочинства та із чиєї ініціативи воно може бути винесено тощо. Російський дослідник М.В. Бєляєв виділяє як етапи ухвалення судового рішення аналіз приводу прийняття судового рішення, яким виступає якась правова ситуація, що потребує свого розв'язання; встановлення фактичних обставин, необхідних для прийняття рішення (насамперед підстав та умов для винесення судового акта); вибір норми права, що підлягає застосуванню; винесення та оформлення рішення [5, с. 12-15]. Недоліком запропонованого підходу $\epsilon$ те, що фактично етапи ухвалення судового рішення відбивають інші елементи механізму прийняття судового рішення.

Більш слушною $\epsilon$ позиція Н.В. Николиної, яка серед етапів правозастосування, котрим беззаперечно $є$ й ухвалення судового рішення, виділяє такі:

1) встановлення та дослідження фактичних обставин справи, що містить такі процедури: з'ясування реальних життєвих фактів, обставин дійсності, котрі торкаються предмета справи, причому необхідно з'ясувати питання наявності й характеристики суб'єктів, об'єкта й змісту відповідних суспільних відносин; дослідження вказаних реальних життєвих фактів, обставин дійсності, що здійснюються уповноваженим суб'єктом шляхом усвідомлення отриманої інформації, іiі вивчення, критичного оцінювання на предмет вірогідності й вироблення загальних уявлень про обставини справи;

2) юридична кваліфікація справи, що передбачає такі процедури: вибір кола норм права, які регламентують юридичні наслідки в разі настання відповідних життєвих обставин; надання правової оцінки всій сукупності фактичних обставин у справі; формування волі в суб'єкта правозастосування щодо прийняття правозастосовного рішення у справі;

3) винесення рішення уповноваженим суб'єктом правозастосування, змістом якої $\epsilon$ такі процедури: підготовка правозастосовного рішення у справі; доведення змісту правозастосовного рішення до відома зацікавлених осіб та організацій; роз'яснення правозастосовного рішення (за необхідності) [6, с. 69].

Специфіка правозастосування в судовій діяльності під час ухвалення судового рішення проявляється в такому.
Спочатку встановлення та дослідження фактичних обставин справи суд аналізує привід прийняття судового рішення, яким виступає якась правова ситуація, що потребує свого розв'язання, - як саму цивільну справу в цілому (тобто розв'язання матеріально-правового питання), так і певну процесуальну питання. Дослідження доказів у суді першої інстанції за правилами цивільної процесуальної форми може бути двояке: попереднє (проводиться з метою здійснення попередньої оцінки доказів на предмет їх належності й допустимості до цивільної справи) й остаточне [7, с. 26]. Як правильно зазначає В.Д. Андрійцьо, процедура попереднього дослідження кардинально відрізняється від процедури кінцевого дослідження, оскільки може проводитися без осіб, які беруть участь у справі, не в залі судового засідання, негласно, презюмуватися тощо [8, с. 10]. У разі винесення рішення чи постанови судом проводиться попередня та остаточна оцінка наявних доказів судом, дослідження фактичних обставин справи. Під час попередньої оцінки доказів суд лише готується до ухвалення рішення, однак, щоб його ухвалити, суд має переконатися, що сторони вжили всіх належних заходів із доведення тих обставин, на які вони посилаються, а суд виконав усі вимоги процесуального законодавства.

Особливо такий етап проявляється в позовному провадженні з проведенням судового засідання: якщо під час судових дебатів виникає необхідність з'ясування нових обставин, що мають значення для справи, або дослідження нових доказів, суд постановляє ухвалу про повернення до з'ясування обставин у справі. Якщо ж судом із певних причин не було виявлено необхідності з'ясування нових обставин, що мають значення для справи, або дослідження нових доказів, до виходу суду для ухвалення рішення суд, не приймаючи рішення, може постановити ухвалу про поновлення судового розгляду для з'ясування будь-якої обставини шляхом повторного допиту свідків або вчинення певної процесуальної дії (ст. 244 цПК України). Однак у будь-якому випадку суд, принаймні формально, перед виходом до нарадчої кімнати має переконатися, що обставини справи з'ясовані в обсязі, достатньому для винесення судового рішення.

Якщо йдеться про розпорядчі судові акти, попередня оцінка може не проводитися, оскільки суд одразу може ухвалити певне рішення, а в разі, коли попередня оцінка доказів все ж необхідна, проводиться вона не щодо усієї справи, а лише в межах того процесуального питання, що підлягає 
розв'язанню. Наприклад, розв'язуючи питання щодо забезпечення позову, суд встановлює зв'язок між тією вимогою, яка заявлена позивачем, i засобом забезпечення позову, який має виключити ускладнення чи унеможливлення виконання рішення суду; розв'язання питання про вимогу доказу чи оригіналу доказу суд встановлює зв'язок між таким доказом і фактом, який ним підтверджується, наявність інших доказів у справі, якими доводиться той самий факт, а також значення встановлення такого факту для розв'язання справи.

Юридична кваліфікація справи, проявляючись в обґрунтуванні судового рішення, $\epsilon$ важливим етапом саме для судових рішень, викладених письмово. Саме на такому етапі суд обирає норму законодавства, яка підлягає застосуванню. Слід погодитися з П.А. Лупинською, що прогнозування наслідків прийнятого рішення також слід розглядати як невіддільну частину вибору правових норм, які підлягають застосуванню [9, с. 58], а не як самостійний етап: вибір норми права передбачає не тільки ії зіставлення з встановленими фактичними обставинами справи, а й прогнозування наслідків їі застосування. Особливо яскраво важливість урахування наслідків прийнятого рішення можуть проілюструвати справи щодо відібрання дитини: в такій категорії справ суд має враховувати думку самої дитини, якщо вона може бути висловлена, задля «забезпечення якнайкращих інтересів дитини» - принципу, що закріплений у Конвенції про права дитини від 20 листопада 1989 року. Так само наслідки прийнятого рішення аналізуються судом під час розв'язання питання про застосування ефективного способу захисту в спірних правовідносинах, який має виключити повторне звернення позивача до суду.

Оформлення судового рішення має свою специфіку залежно від:

форми (вербальної чи письмової): ухвали суду, які оформлюються окремим документом, рішення суду й постанови приймаються, складаються та підписуються в нарадчій кімнаті;

виду судового рішення, адже процесуальне законодавство визначає дещо різні вимоги щодо форми й змісту ухвал, рішень і постанов, а до окремих видів ухвал можуть бути встановлені додаткові вимоги щодо змісту (наприклад, ухвали про тимчасове вилучення доказів для дослідження судом, стягнення штрафу, забезпечення позову, затвердження мирової угоди $є$ виконавчим документом, а тому мають відповідати вимогам до виконавчого документа).
Проголошення судового рішення залежить не стільки від його виду (оскільки будь-яке судове рішення, крім судового наказу, може бути проголошене), скільки від явки всіх учасників справи в судове засідання, яким завершується розгляд справи, чи розгляду справи без повідомлення (виклику) учасників справи - в такому випадку суд підписує рішення без його проголошення.

Водночас контроль за виконанням судового рішення не входить до стадій його прийняття, оскільки, по-перше, цивільне процесуальне законодавство (на відміну від адміністративного судочинства) не наділяє суд правом здійснення такого контролю, а по-друге, такі дії семантично виходять за межі процедури його прийняття. Як вже було зазначено вище, перегляд судових рішень судами апеляційної та касаційної інстанції так само не входить до механізму ухвалення судового рішення, оскільки відбувається після винесення судового рішення, а у визначених законом випадках - після набрання рішенням законної сили. 3 цих же причин не можна назвати контролем за виконанням судового рішення скасування судом власного рішення (скасування ухвали про забезпечення позову й про зустрічне забезпечення чи заходів забезпечення позову, судового наказу, заочного рішення тощо), адже в такому випадку процесуальна діяльність суду утворює самостійний склад механізму ухвалення судового рішення, в якому предметом будуть вже інші обставини, які заново мають бути досліджені судом.

Висновки. Повертаючись до питання про структурні елементи механізму прийняття судового рішення, до їх числа можуть бути віднесені: суб'єкти діяльності з прийняття рішень, що володіють певним колом повноважень; об'єкт судового рішення; мета ухвалення судового рішення; підстави ухвалення судового рішення; етапи ухвалення судового рішення.

\section{Література}

1. Чертова Н.А., Юринская И.С. Механизм принятия судебного решения: теоретические аспекты. Вестник Северного (Арктического) федерального университета. Серия: Гуманитарные и социальные науки. 2015. № 3. С. 120.

2. Андронов І.В. Судові рішення в цивільному процесі України : дис. ... д-ра юрид. наук : 12.00.03. Одеса, 2018. 435 с.

3. Судебная власть. Научное издание / Т.Е. Абова, Е.Б. Абросимова, М.В. Боровский, С.В. Булаковский и др. ; Отв. ред.: И.Л. Петрухин. Москва : 000 «ТК Велби», 2003. 720 с. 


\section{Проблеми цивільного та господарського права}

4. Загайнова С.К. Судебные акты в гражданском и арбитражном процессе : теоретические и прикладные проблемы : автореф. дис. ... д-ра юрид. наук : 12.00.05. Екатеринбург, 2008. 51 с.

5. Беляев М.В. Судебные решения в российском уголовном процессе: теоретические основы, законодательство и практика : автореф. дис. ... д-ра юрид. наук : 12.00.09. Москва, 2019. 55 с.

6. Николина К.В. Особливості процедурних засад правозастосовної діяльності. Часопис Київського університету права. 2011. № 2. С. 67-70.

7. Баулин О.В. Фильченко Д.Г. Доказательства и доказывание в гражданском судопроизводстве. Воронеж : Издательство Воронежского государственного университета, 2006. 264 с.
8. Андрійцьо. В.Д. Дослідження доказів як етап процесу доказування в цивільному судочинстві. Bicник Вищої ради юстиції. 2013. № 3. С. 7-17. URL: http://nbuv.gov.ua/UJRN/vvru_2013_3_3. C. 10.

9. Лупинская П.А. Решения в уголовном судопроизводстве. Их виды, содержание и формы. Москва : Юрид. лит., 1976. 167 с.

Прохоров П. А., аспірант кафедри цивільного процесу Національного університету "Одеська юридична академія", суддя Київського районного суду міста Одеси 